\title{
Pszczoły MIOdNE W PRAWIE MIEJSCOWYM
}

\section{Wstęp}

W europejskich miastach coraz częściej spotyka się ule pszczele, ulokowane na dachach budynków lub na publicznie dostępnych terenach zielonych. Pszczelarstwo miejskie zyskuje na popularności, choć nie jest nowym zjawiskiem - ma już ponad stuletnią tradycję․ Chowu pszczół miodnych $\mathrm{w}$ miastach nie należy postrzegać jako kaprysu czy fanaberii, bowiem działalność ta opiera się na istotnych, środowiskowych przesłankach. Ekosystemowe znaczenie pszczół nie ulega wątpliwości. Są one najbardziej efektywnymi zapylaczami - tak skupisk roślinności dzikiej, jak i nadzorowanych przez człowieka upraw ${ }^{2}$. Tymczasem w ciągu ostatnich kilkunastu lat zaobserwowano zjawisko masowego ginięcia populacji pszczół (colony collapse disorder, CCD). Skłoniło to przedstawicieli nauki do poszukiwania przyczyn tego zjawiska, a także obszarów, które mogłyby stanowić bezpieczną przystań dla pszczół. W dobie intensywnego

* Dr hab., Uniwersytet Śląski, radca prawny; e-mail: agnieszka.bielska-brodziak@ us.edu.pl, ORCID ID: https:// orcid.org/0000-0002-9926-6436.

** Doktorantka Uniwersytetu Śląskiego; e-mail: mdrapalska@gmail.com, ORCID ID: https:/ / orcid.org/0000-0002-8602-2918.

*** Doktorant Uniwersytetu Śląskiego; e-mail: m.suska@poczta.onet.pl, ORCID ID: https:/ / orcid.org/0000-0002-0950-5588.

1 Na przykład paryskie pasieki na Operze Garnier oraz w Ogrodach Luksemburskich, https://www.nytimes.com/2018/08/24/world/europe/bees-paris.html [dostęp: 20.08.2019 r.].

2 Zob. L. Valentin, Challenges and Opportunities in Swedish Apiculture [online], Uppsala 2012, https://stud.epsilon.slu.se/6181/8/valentin_1_131015.pdf [dostęp: 20.08.2019 r.]. 
wykorzystywania środków ochrony roślin, tradycyjnie zasiedlana przez pszczoły przestrzeń wiejska stała się mniej przyjaznym miejscem do ży$\mathrm{cia}^{3}$. Problem stanowi również powstawanie monokultur, a co za tym idzie - zubożenie pszczelej bazy pokarmowej. Jak wskazują badania, pszczoły mogą mieć w miastach dobre warunki bytowania ${ }^{4}$, m.in. dzięki ich różnorodności ${ }^{5}$. Pszczoły mają tu dostęp do zróżnicowanych miejsc odpoczynku i żerowania 6 . Co chyba jeszcze ważniejsze, miasta oferują zapylaczom różnorodny pokarm7, ponieważ sadzi się tam wiele gatunków roślin kwiatowych oraz utrzymuje łąki pełne dzikiej roślinności.

Celem niniejszego opracowania jest dokonanie formalnodogmatycznej analizy obowiązujących przepisów ustaw oraz aktów prawa miejscowego, których przedmiotem jest status pszczół utrzymywanych na obszarach miejskich. Centralnym obiektem naszych zainteresowań są pszczoły miodne. Nie jest nim zaś pszczelarstwo rozumiane jako pewien rodzaj działalności gospodarczej, choć oczywiście oba te zagadnienia są ze sobą ściśle związane, przynajmniej $\mathrm{w}$ pewnych punktach. Wychodzimy $\mathrm{z}$ założenia, że zwiększanie populacji pszczół w miastach jest godne poparcia ze względów ochrony środowiska oraz ochrony gatunkowej. Prawo musi jednak zapewnić harmonijne współżycie ludzi i pszczół w specyficznym środowisku miejskim. Ciężar ustanowienia takich regulacji w chwili obecnej jest przeniesiony na gminy i na nich w dalszym ciągu powinien spoczywać. Interesuje nas również, czy w prawie daje się zidentyfikować elementy ochrony pszczół ze względu na ich samoistną wartość jako zwierząt - a zatem ochrony nazywanej zwykle humanitarną.

3 Zob. P. Michołap, A. Sikora, Dzikie pszczoły w mieście i możliwości ich protekcji, w: Ochrona pszczót i pszczelarstwo w badaniach młodych naukowców, red. E.M. Szymański, D. Dyrda, Zgorzelec 2016, s. 80-90.

4 Zob. G.A. Langellotto i in., Garden Pollinators and the Potential for Ecosystem Service Flow to Urban and Peri-Urban Agriculture, Sustainability 2018, t. 10 oraz A.E. Samuelson i in., City Bees out Breed their Country Cousins [online], https:/ / www.royalholloway.ac.uk/ about-us/news/city-bees-out-breed-their-country-cousins/ [dostęp: 20.08.2019 r.].

5 Zob. W. Banaszak-Cibicka i in., City Parks vs. Natural Areas - Is It Possible to Preserve a Natural Level of Bee Richness and Abundance in a City Park?, Urban Ecosystem 2018, t. 21, s. 599-613.

6 Tak przykładowo: K.C. Matteson, J.S. Ascher, G.A. Langellotto, Bee Richness and Abundance in New York City Urban Gardens, Annals of the Entomological Society of America 2008, t. 101, s. 140.

7 Zob. A. Burr i in., Wild Bees in the City: Reimagining Urban Spaces for Native Bee Health, Consilience: The Journal of Sustainable Development 2016, t. 16, s. 108. 


\section{Wspieranie obecności pszczół w miastach}

Prawo ma potencjał, by istotnie przyczynić się do rozwoju pszczelarstwa miejskiego. Może ono m.in. służyć transformacji przestrzeni miejskiej tak, by była jak najbardziej przyjazna potrzebom pszczół. Wydaje się, że najlepszym sposobem wspierania obecności pszczół jest tworzenie ogrodów, parków czy skwerów, a następnie zadbanie, by obfitowały one w mnogość gatunków roślin kwiatowych, kwitnących w różnych okresach. Także żywopłoty powinny składać się z roślin kwitnących, najlepiej całorocznych. Dobrze jest zapewnić tym owadom stały dostęp do wody (np. w małych stawach czy sadzawkach $)^{8}$. W tego rodzaju działania można również - poprzez odpowiednie zachęty - włączyć właścicieli mieszkań i nieruchomości gruntowych. Warto w tym kontekście wspomnieć o idei "pszczelej autostrady”, która powstaje w Oslo. Chodzi tu o stworzenie owadom bezpiecznych warunków przemieszczania się, a to dzięki ustawianiu na balkonach i dachach roślin, pojemników z wodą oraz domków dla pszczół. Pomiędzy tak utworzonymi kwitnącymi dachami i balkonami ma biec swoista trasa, ułatwiająca owadom migrację i zasiedlanie domowych uli9. Z kolei w Ljubljanie prężnie działa społeczna inicjatywa Bee Path Project ${ }^{10}$. W ramach projektu obywatele są zachęcani do sadzenia roślin nektarowych i mają możliwość uzyskania ich nasion. W stolicy Słowenii same władze tworzą ponadto wiele obszarów przyjaznych pszczołom ${ }^{11}$.

Powyższe działania z natury rzeczy muszą mieć charakter lokalny. W gminach władze samorządowe mogą kooperować ze związkami

8 Helping Honey Bees and other London Pollinators [online], http:/ / www.lbka.org.uk/ downloads/LBKA_helping_honey_bees_A4_digital_v3.pdf [dostęp: 1.09.2019 r.]; J. Marinelli, Urban Refuge: How Cities Can Help Rebuild Declining Bee Populations [online], https:/ / e360.yale.edu/features/urban-refuge-how-cities-can-help-rebuild-declining-bee-populations [dostęp: 20.08.2019 r.].

9 Zob. Oslo Creates World's First "Highway" to Protect Endangered Bees [online], The Guardian, https:/ /www.theguardian.com/environment/2015/jun/25/oslo-createsworlds-first -highway-to-protect-endangered-bees [dostęp: 20.08.2019 r.].

10 Zob. N. Ilič, BeePathNet Boot Camp [online], https://zavodeneja.wixsite.com/api-programi/single-post/2019/04/15/BeePathNet oraz [online], https://urbact.eu/bee-path [dostęp: 20.08.2019 r.].

11 Zob. Ljubljana Most Bee-Friendly Municipality 2017 [online], https:/ /www.ljubljana. si/en/about-ljubljana/award-winning-ljubljana/ljubljana-most-bee-friendly-municipality-2/ [dostęp: 20.08.2019 r.]. 
pszczelarskimi oraz innymi organizacjami pozarządowymi. Współpraca ta może zaowocować doborem najlepszych dla pszczół drzew i kwiatów ${ }^{12}$, a także ustaleniu jak najlepszej dystrybucji tych roślin. Taka kooperacja może też pomóc w podejmowaniu decyzji co do opustoszałych przestrzeni miejskich, tak by nie likwidować istniejących tam dzikich łąk.

Współpraca ze związkami pszczelarskimi i innymi organizacjami pozarządowymi może również służyć prowadzeniu edukacji skierowanej do społeczności lokalnej. Chodzi tu o rozwój zbiorowej wiedzy o znaczeniu pszczół dla człowieka, o obyczajach tych owadów oraz - a może przede wszystkim o tym, że nie tworzą one istotnego zagrożenia. Tego rodzaju działania można prowadzić choćby w miejskich pasiekach edukacyjnych, ale i - znanych we wspominanej tu już Ljubljanie - szkolnych klubach pszczelarskich ${ }^{13}$.

\section{Cywilno- i karnoprawne aspekty pszczelarstwa miejskiego}

Od razu trzeba zaznaczyć, że Kodeks cywilny ${ }^{14}$ nie przewiduje niemal żadnych szczególnych regulacji dotyczących pszczelarstwa. W większości sytuacji zastosowanie znajdą przepisy ogólne. Problematyka pszczela doczekała się dostrzeżenia w art. 182 K.c., gdzie prawodawca przewidział szczególny sposób utraty i nabycia własności na skutek wyrojenia się pszczół. Wyrojenie może być spowodowane niekorzystnymi warunkami, takimi jak ciasnota, przegrzanie czy brak pożywienia. Niekiedy stanowi zaś naturalny proces związany z rozmnażaniem się rodziny pszczelej. Zasadniczo jednak niekontrolowana rójka jest stanem niepożądanym, a zadaniem wykwalifikowanego pszczelarza jest zapobieżenie jej. Jest to szczególnie ważne na gęsto zaludnionych obszarach miejskich. Pszczoły, pomimo ich niezwykle pozytywnej roli w ekosystemie, mogą być zwierzętami niebezpiecznymi dla życia i zdrowia człowieka oraz innych zwierząt, a to ze względu na toksyczne właściwości ich jadu ${ }^{15}$. Jad pojedynczej

12 Helping Honey Bees...

13 Zob. The Bee Path [online], https://www.ljubljana.si/en/ljubljana-for-you/environmental-protection/the-bee-path/ [dostęp: 20.08.2019 r.].

14 Ustawa z dnia 23 kwietnia 1964 r. - Kodeks cywilny, tekst jednolity: Dz. U. z 2019 r. poz. 1145 z późn. zm. (dalej: K.c.).

15 Zob. J. Buczek, Cywilnoprawna problematyka hodowli pszczót, Przegląd Sądowy 2003, nr 2, s. 48. 
pszczoły nie stanowi zazwyczaj dla człowieka zagrożenia, lecz rój składa się z kilku tysięcy pszczół. Nawet jeżeli rój nie jest agresywny, widok tak dużej liczby owadów pozostających poza ulem może budzić lęk wśród członków społeczności lokalnych oraz pogarszać społeczne oceny pszczelarstwa miejskiego.

Wspomniany tu art. 182 K.c. nie odpowiada na powyższe zagrożenia. Celem tego przepisu nie jest ochrona przed skutkami rójki, ale ustalenie, kto jest właścicielem wyrojonych pszczół i jakie w związku z tym przysługują mu prawa. Przepis ten w żaden sposób nie obliguje, ani nawet nie zachęca, pszczelarza do zapobieżenia rójce - chyba żeby za swoistą "zachętę" uznać groźbę utraty pszczół na rzecz innego pszczelarza.

Istotniejsze w tym względzie wydają się roszczenia $\mathrm{z}$ tytułu odpowiedzialności za szkodę bądź krzywdę oraz z tytułu naruszenia prawa własności przez immisje. Odpowiedzialność na zasadach ogólnych (art. 415 K.c.) ma miejsce w przypadku możliwości zarzucenia pszczelarzowi winy. Gdy zwierzę spowodowało szkodę „własnym popędem”, a więc spontanicznie, niezależnie od dyspozycji wydawanych mu przez człowieka, zastosowanie znajdzie art. 431 K.c. ${ }^{16}$

Z kolei zgodnie z art. 144 K.c., właściciel nieruchomości powinien przy wykonywaniu swego prawa powstrzymywać się od działań, które by zakłócały korzystanie z nieruchomości sąsiednich ponad przeciętną miarę, wynikającą ze społeczno-gospodarczego przeznaczenia nieruchomości i stosunków miejscowych. Niepożądane oddziaływania na okoliczne nieruchomości nazywamy immisjami. Ich źródłem może być również utrzymywanie zwierząt ${ }^{17}$. Im mniejsze nieruchomości, im gęściej zabudowany i zaludniony obszar, tym większe jest ryzyko wystąpienia immisji, a zatem problematyka ta nabiera szczególnego znaczenia właśnie na terenach miejskich. Immisje tradycyjnie dzieli się na materialne i niematerialne. W przypadku immisji powodowanych przez pszczoły wystąpić mogą oba rodzaje tych niepożądanych oddziaływań. Przykładem pierwszych może być żądlenie ludzi i zwierząt na sąsiednich nieruchomościach, zaś przykładem drugich - sam lęk przed użądleniem wzbudzany przez

16 Zob. G. Bieniek, J. Gudowski, Komentarz do art. 432 Kodeksu cywilnego, w: Kodeks cywilny. Komentarz, t. 3. Zobowiązania. Część ogólna, red. J. Gudowski, Wolters Kluwer Polska 2018; wyrok SA w Łodzi z dnia 8 kwietnia 2015 r., I ACa 1472/14, LEX nr 1680038.

17 Zob. A. Haładyj, J. Trzewik, Lokalizacja pni pszczelich na tle regulacji prawa administracyjnego i prawa cywilnego, Studia Prawnoustrojowe 2017, nr 37, s. 163. 
przelatujące pszczoły ${ }^{18}$. Trzeba jednak zdecydowanie podkreślić, że ustawodawca w art. 144 K.c. nie zabronił wszelkich immisji, lecz tylko tych, które przekraczają „przeciętną miarę wynikającą ze społeczno-gospodarczego przeznaczenia nieruchomości i stosunków miejscowych". Oceniając przesłankę „przeciętnej miary” należy brać pod uwagę rolę pszczół w środowisku przyrodniczym, ich znaczenie dla społeczeństwa, ale także niebezpieczeństwo, jakie mogą spowodować dla zdrowia i życia ludzi - tak aby osiągnięto harmonię pomiędzy interesem jednostki i ogółu przy równoczesnej ochronie środowiska naturalnego ${ }^{19}$. Immisje mogą uzasadniać pomniejszenie pasieki, przeniesienie jej w inne miejsce, wymianę matek lub nawet usunięcie pasieki ${ }^{20}$.

Istotnego znaczenia $\mathrm{w}$ kontekście immisji nabiera kwestia rozmieszczenia pasiek. Obecnie ani K.c., ani żadna ustawa szczególna nie reguluje lokalizacji pasieki. Wobec tego właściciel nieruchomości może rozmieszczać pasieki w dowolnej liczbie i odległości na swojej nieruchomości. Musi jednak wziąć pod uwagę treść art. 144 K.c. W praktyce pszczelarze poszukujący wytycznych co do odpowiedniej lokalizacji pasieki korzystają ze wskazań zawartych w Kodeksie Dobrych Praktyk Produkcyjnych w Pszczelarstwie (KDPP). Nie jest to źródło prawa ${ }^{21}$, ale nic nie stoi na przeszkodzie, by pszczelarze dobrowolnie dostosowywali swoją działalność do wymogów stawianych przez kodeks - będzie to świadczyło o dochowaniu środków ostrożności przez prowadzącego pasiekę.

Z perspektywy prawa karnego najbardziej znaczące wydaje się wykroczenie niezachowania zwykłych lub nakazanych środków ostrożności przy trzymaniu zwierząt, stypizowane w art. 77 Kodeksu wykroczeń22. W przypadku pszczół dużą wagę będzie miało właściwe ulokowanie

18 Zob. M. Goettel, Sytuacja zwierzęcia w prawie cywilnym, Warszawa 2013, s. 78.

19 Zob. wyrok SN z dnia 28 grudnia 1979 r., III CRN 249/79, OSNC 1980/7-8/144; wyrok SR w Gorlicach z dnia 7 grudnia 2016 r., I C 255/16; wyrok SA w Białymstoku z dnia 1 marca 2013 r., I ACa 835/12, LEX nr 1294703.

20 Zob. wyrok SR w Suchej Beskidzkiej z dnia 20 lipca 2016 r., I C 19/15, http:/ / orzeczenia.ms.gov.pl/details / \$N/152010550000503_I_C_000019_2015_Uz_2016-07-20_001 [dostęp: 20.08.2019 r.]

21 Zob. wyrok SR w Świdnicy z dnia 25 stycznia 2017 r., I C 1522/16, http:/ / orzeczenia.swidnica.sr.gov.pl/details/\$N/155020150000503_I_C_001522_2016_Uz_2017-0206_001 [dostęp: 20.08.2019 r.].

22 Ustawa z dnia 20 maja 1971 r. - Kodeks wykroczeń, tekst jednolity: Dz. U. z 2019 r. poz. 821 z późn. zm. (dalej: K.w.). 
pasieki, tak aby nie znajdowała się zbyt blisko domów mieszkalnych czy miejsc użyteczności publicznej. Środkiem ostrożności może być także oznaczenie terenu stosownymi tabliczkami. Niezachowanie zwykłych lub nakazanych środków ostrożności jest zagrożone karą grzywny do 1000 złotych lub karą ograniczenia wolności. Jeżeli jednak chodzi o zwierzę, „które swoim zachowaniem stwarza niebezpieczeństwo dla życia lub zdrowia człowieka", maksymalny wymiar grzywny zwiększa się do 5000 złotych ${ }^{23}$; jak się wydaje, pszczoły mogłyby być uznane za tego rodzaju zwierzęta.

Pokrótce scharakteryzowane instrumenty prawa cywilnego i karnego nie przystają do wyzwań, jakie rodzi utrzymywanie pszczół w miastach. W mieście trzeba przede wszystkim zapewnić bezkolizyjne funkcjonowanie pszczół wśród ludzi i to na gęsto zaludnionym obszarze. Przepisy dotyczące odpowiedzialności za szkodę lub krzywdę mają charakter instrumentów wdrażanych post factum. Dodatkowo ich zastosowanie może się wiązać z licznymi problemami dowodowymi - nie zawsze przecież można udowodnić, że to właśnie pszczoły konkretnego właściciela odpowiadają za przykre w skutkach pożądlenie. Nieco bardziej adekwatny zdaje się być przepis art. 77 K.w., jednakże jest on zbyt ogólny i nie wskazuje minimalnych środków bezpieczeństwa, jakie powinny być zachowane przez pszczelarzy. Stosunkowo najbardziej odpowiednie do zastosowania w warunkach miejskich wydają się roszczenia przysługujące właścicielowi nieruchomości z tytułu immisji - zwłaszcza, że można je podnieść również wtedy, gdy nie doszło jeszcze do powstania szkody lub krzywdy. Jednakże ten tradycyjny instrument prawa cywilnego jest dostosowany do sporów między prywatnymi właścicielami nieruchomości. W miastach bardzo ważne jest zaś zapewnienie bezpieczeństwa użytkownikom obiektów użyteczności publicznej, w tym dróg, osobom trzecim, które nie mogą bronić się za pomocą roszczeń windykacyjnych lub negatoryjnych. Wyzwaniom tworzonym przez pszczelarstwo miejskie najlepiej odpowiedzieć może prawo administracyjne - ustanawiające obowiązki publicznoprawne, regulujące zasady korzystania z rzeczy publicznych i dodatkowo otwarte na dostosowanie do warunków lokalnych. 


\section{Regulamin utrzymania czystości i porządku w gminie}

Warunki utrzymywania pszczół w miastach nie są jednolite dla całego obszaru Polski, ponieważ ustawodawca powierzył ich ustanowienie radom gmin. Organ ten, na podstawie art. 4 ust. 1-2a ustawy z dnia 13 września 1996 r. o utrzymaniu czystości i porządku w gminach ${ }^{24}$, wydaje regulamin utrzymania czystości i porządku na terenie gminy, będący aktem prawa miejscowego. Jedną z jego części ma być określenie „wymagań utrzymywania zwierząt gospodarskich na terenach wyłączonych z produkcji rolniczej, w tym także zakazu ich utrzymywania na określonych obszarach lub w poszczególnych nieruchomościach"25.

To, czy zacytowana kompetencja rady gminy obejmuje też możliwość określenia wymagań utrzymywania pszczół, zależy od rozumienia pojęcia „zwierząt gospodarskich". Definicję tego pojęcia odnaleźć można w ustawie o organizacji hodowli i rozrodzie zwierząt gospodarskich ${ }^{26}$. Przepisy art. 2 pkt 1-3 ustawy o organizacji hodowli i rozrodzie zwierząt gospodarskich wymieniają szereg gatunków zwierząt uznawanych za gospodarskie, a pośród nich została umieszczona pszczoła miodna (Apis mellifera). W nauce zasygnalizowano już wątpliwość, czy definicja z ustawy o organizacji hodowli i rozrodzie zwierząt gospodarskich może być wprost stosowana na potrzeby określenia, wobec jakich gatunków zwierząt można ustanawiać wymagania w regulaminie. Głównym celem ustanawiania $\mathrm{w}$ regulaminie wymagań utrzymywania zwierząt gospodarskich jest przecież utrzymanie czystości i porządku. W regulaminie trzeba więc zwrócić uwagę na gatunki,

których chów i hodowla zalicza się do uciążliwych ze względu na ilość powstających $\mathrm{w}$ związku z tą działalnością odchodów [...], uciążliwościami odorowymi czy też znacznym areałem potrzebnym do prowadzenia chowu lub hodowli w sposób humanitarny lub zgodny z przepisami sanitarno-weterynaryjnymi. Żadna z tych uciążliwości dla życia i zdrowia ludzi, jak też środowiska nie powstaje jednak w związku z hodowlą pszczół ${ }^{27}$.

24 Ustawa z dnia 13 września 1996 r. o utrzymaniu czystości i porządku w gminach, tekst jednolity: Dz. U. z 2019 r. poz. 2010 z późn. zm.

${ }^{25}$ Art. 4 ust. 2 pkt 7 ustawy o utrzymaniu czystości i porządku w gminach.

26 Ustawa z dnia 29 czerwca 2007 r. o organizacji hodowli i rozrodzie zwierząt gospodarskich, tekst jednolity: Dz. U. z 2017 r. poz. 2132.

27 A. Haładyj, J. Trzewik, Lokalizacja pni pszczelich..., s. 150. 
Większość doktryny zdaje się jednak nie podzielać tych wątpliwości²8, a co jeszcze istotniejsze - nie przychylają się do nich wojewodowie i sądy administracyjne. $\mathrm{W}$ trakcie naszych analiz nie spotkaliśmy się z sytuacją, by jakiejkolwiek gminie uczyniono zarzut z samego faktu ustanowienia reżimu prawnego właśnie dla pszczół. Ponadto w orzecznictwie wprost wskazywano, że pojęcie „zwierząt gospodarskich” trzeba rozumieć zgodnie $\mathrm{z}$ definicją z ustawy o organizacji hodowli i rozrodzie zwierząt gospodarskich $^{29}$.

Ustanowienie warunków chowu pszczół mieści się więc w kompetencji przyznanej radzie gminy na podstawie art. 4 ust. 2 pkt 6 ustawy o utrzymaniu czystości i porządku w gminach. Z pewnością jednak cytowanym autorom trzeba przyznać rację, że utrzymywanie pszczół znacząco różni się od utrzymywania innych zwierząt gospodarskich - przede wszystkim pod względem rodzaju oddziaływania na otoczenie. W tym przypadku głównym celem potencjalnych ograniczeń z natury rzeczy nie będzie zapewnienie ochrony przed nieczystościami czy uciążliwościami odorowymi lub akustycznymi. Będzie to raczej ochrona przed pożądleniem oraz lękiem o życie i zdrowie - co wydaje się mieścić przynajmniej w pojęciu „utrzymania porządku”.

Zakres kompetencji rad gmin w omawianym aspekcie ograniczono do „terenów wyłączonych z produkcji rolniczej”. Pojęcie to w orzecznictwie ${ }^{30}$ rozumiane jest w świetle wskazań ustawy z dnia 3 lutego 1995 r. o ochronie gruntów rolnych i leśnych ${ }^{31}$. Zakresu władztwa gminy nie wyznacza więc fakt, czy w miejscowym planie zagospodarowania przestrzennego teren został przeznaczony na cele nierolne ${ }^{32}$ lub czy wydano decyzję ze-

28 ,"...] polskie ustawodawstwo do zwierząt gospodarskich zalicza wprost pszczoły. Dlatego art. 4 ust. 2 pkt 7 u.p.c.g. pozwala wprowadzić w regulaminie odpowiednie ograniczenia dotyczące np. liczby uli na terenach wyłączonych z produkcji rolniczej, ich odległości od sąsiednich nieruchomości czy dróg, a nawet zakaz hodowli pszczół na określonych obszarach", W. Radecki, Komentarz do art. 4 ustawy o utrzymaniu czystości i porządku w gminach, LEX 2016.

${ }_{29}$ Zob. wyrok NSA z dnia 29 kwietnia 2009 r., II OSK 1953/08, LEX nr 597454.

30 Zob. decyzjaSKO w Katowicach z dnia 7 stycznia 2014 r., SKO-OG/43/75/13875/13, LEX nr 1427612; wyrok WSA w Warszawie z dnia 11 września 2015 r., IV SA/Wa 1435/15, LEX nr 2327557; wyrok WSA w Warszawie z dnia 10 lutego 2017 r., IV SA/Wa 2661/16, LEX nr 2396075.

31 Ustawa z dnia 3 lutego 1995 r. o ochronie gruntów rolnych i leśnych, tekst jednolity: Dz. U. z 2017 r. poz. 1161.

32 Zob. art. 7 ust. 1 ustawy o ochronie gruntów rolnych i leśnych. 
zwalającą na wyłączenie gruntów z produkcji rolnej ${ }^{33}$. Niezbędne jest, by po wydaniu tych aktów doszło do rzeczywistego rozpoczęcia innego niż rolne użytkowania gruntów ${ }^{34}$.

\section{Lokalne regulacje dotyczące utrzymywania pszczół w miastach}

Na potrzeby opracowania dokonano przeglądu regulaminów utrzymania czystości i porządku na terenie gminy, obowiązujących ${ }^{35}$ na obszarze 39 najludniejszych polskich miast, to znaczy zamieszkiwanych przez co najmniej 100 tys. osób ${ }^{36}$. Można zauważyć, że w tej grupie aż w 17 regulaminach nie pojawia się żadna wzmianka o utrzymywaniu pszczół. Prawodawcy lokalni nie dostrzegli więc potrzeby, by status tych zwierząt uregulować odmiennie niż pozostałych zwierząt gospodarskich (mimo że pszczoły są zwierzętami inaczej oddziałującymi na środowisko niż choćby indyki czy kozy). Stosunkowo najczęściej zezwala się na utrzymywanie zwierząt gospodarskich na wszystkich lub niektórych terenach wyłączonych z produkcji rolniczej, pod warunkiem „niepowodowania uciążliwości" dla otoczenia czy mieszkańców sąsiednich nieruchomości ${ }^{37}$.

Tak ogólne wymogi dają się zastosować do chowu pszczól, choć nie stanowią dla pszczelarzy szczególnie przydatnej miary oceny własnych działań. Jednakże w ponad połowie z 17 wspomnianych miast niedostrzeżenie odmienności pszczół może prowadzić do uznania, że ich utrzymywanie jest zakazane - oczywiście jedynie na terenach wyłączonych

33 Zob. art. 11 ustawy o ochronie gruntów rolnych i leśnych.

34 Zob. art. 4 pkt 11 ustawy o ochronie gruntów rolnych i leśnych.

35 Były to regulaminy obowiązujące w dniu 26 lipca 2019 r.; jedynie w przypadku Rybnika analizie poddano regulamin, który wszedł w życie z dniem 1 stycznia 2020 r. (dalej: regulamin).

36 Według danych ze strony http:/ / www.polskawliczbach.pl/najwieksze_miasta_w_ polsce_pod_wzgledem_liczby_ludnosci [dostęp: 26.07.2019 r.]. Analizie poddano regulaminy z następujących miast: Warszawa, Kraków, Łódź, Wrocław, Poznań, Gdańsk, Szczecin, Bydgoszcz, Lublin, Białystok, Katowice, Gdynia, Częstochowa, Radom, Sosnowiec, Toruń, Kielce, Rzeszów, Gliwice, Zabrze, Olsztyn, Bielsko-Biała, Bytom, Zielona Góra, Rybnik, Ruda Śląska, Opole, Tychy, Gorzów Wielkopolski, Dąbrowa Górnicza, Elbląg, Płock, Wałbrzych, Włocławek, Tarnów, Chorzów, Koszalin, Kalisz oraz Legnica.

37 Np. Gorzów Wielkopolski - § 18 ust. 3 regulaminu, Kielce - $§ 12$ ust. 1 pkt 2 regulaminu. 
z produkcji rolniczej. Tak na przykład w Tarnowie prawodawca ustanowił wymóg, by „[p]omieszczenia dla zwierząt gospodarskich, teren hodowli i bezpośrednie ich otoczenie" ogrodzone były „w sposób uniemożliwiający przedostanie się zwierząt poza ich obręb"38. Dochowanie tych obowiązków w przy padku pszczół miodnych jest niezwykle trudne, a może wręcz niemożliwe. Pszczoły musiałyby być utrzymywane na nieruchomości na tyle dużej, by jej teren wyczerpywał typowy (bądź nawet maksymalny) zasięg pszczelich oblotów ${ }^{39}$. Całkiem niemożliwy jest zaś chów pszczół z zachowaniem ustanowionego w Dąbrowie Górniczej wymagania, by zwierzęta gospodarskie były "utrzymywane w obiektach zamkniętych" ${ }^{40}$. Można jednak podjąć próbę takiej interpretacji, by przez „obiekt zamknięty” rozumieć także ogrodzoną nieruchomość, co zrównywałoby ten wymóg z przytoczonym przykładem z Tarnowa ${ }^{41}$.

W pozostałych 22 przypadkach pszczoły doczekały się - choćby niewielkiej - wzmianki w treści regulaminu, przy czym za najbardziej przyjazne pszczołom miasta należy uznać te, w których ich utrzymywanie zostało dopuszczone na wszystkich terenach wyłączonych z produkcji rolniczej. Tak na przykład w Łodzi ${ }^{42}$, Poznaniu ${ }^{43}$ czy Opolu $^{44}$ ustanowiono specjalne strefy miejskie, w których zakazany jest chów zwierząt gospodarskich, ale zakazem tym nie objęto pszczół ${ }^{45}$. W większości miast nie zezwala się jednak na utrzymywanie pszczół na obszarach, na których nie byłby dopuszczony chów innych zwierząt.

Miasta obwarowują jednocześnie chów pszczół wieloma wymogami, które dla celów omówienia pogrupujemy w cztery kategorie:

$38 \S 23$ ust. 1 regulaminu; podobnie w Sosnowcu - § 22 ust. 1 regulaminu.

39 Na temat maksymalnego zasięgu pszczelich oblotów zob. J.R. Hagler i in., Foraging Range of Honey Bees, "Apis mellifera”, in Alfalfa Seed Production Fields, Journal of Insect Science 2011, t. 11.

$40 \S 21$ ust. 1 regulaminu.

41 Do podobnych konsekwencji zdają się prowadzić postanowienia regulaminów obowiązujących w: Radomiu (§ 18), Rybniku (§ 20 pkt 1), Tychach (§ 16 ust. 4 pkt 2), Rudzie Śląskiej (§ 8 ust. 1); zob. również Wałbrzych - § 13 ust. 2 pkt 6 regulaminu.

$42 \S 20$ ust. 2 regulaminu.

$43 \S 13$ ust. 1 regulaminu.

$44 \S 15$ ust. 8 regulaminu.

45 Łódź - § 20 ust. 2 regulaminu; Poznań - § 13 ust. 1 regulaminu; Opole - § 15 ust. 8 regulaminu; zob. także Szczecin - § 10 ust. 1 pkt 2 regulaminu, Płock - § 19 ust. 1 regulaminu. 
1) nakazy związane z zabezpieczeniem terenów sąsiadujących z pasieką oraz osób z nich korzystających;

2) nakazy dotyczące utrzymywania pszczół na dachach budynków oraz zakazy ich utrzymywania na balkonach i w innych pomieszczeniach nieprzystosowanych do tego celu;

3) nakazy dotyczące wyboru odmian pszczól;

4) zakazy utrzymywania pni pszczelich ponad ustaloną liczbę.

Ad 1. Z ogólnej liczby 22 miast aż w 18 ustanowiono wymogi dotyczące zabezpieczenia terenów sąsiadujących z pasieką oraz osób z nich korzystających. Od razu trzeba zaznaczyć, że w trzech przypadkach chodzi jedynie o ogólny wymóg, by pszczoły były „utrzymywane w miejscach uniemożliwiających swobodny dostęp do uli osobom trzecim, $w$ taki sposób, aby ich obecność nie zakłócała korzystania z nieruchomości sąsiednich i nie stanowiła zagrożenia dla ludzi" ${ }^{46}$.

Najczęściej w regulaminach wskazuje się minimalne odległości od pewnych punktów, które pszczelarze muszą zachować przy podejmowaniu decyzji o lokalizacji pasieki. W wielu przypadkach prawodawcy lokalni wydają się inspirować wskazówkami zaczerpniętymi ze wspomnianego już KDPP.

$\mathrm{W}$ analizowanych regulaminach często nakazuje się zachowanie odległości $10 \mathrm{~m}$ od granicy nieruchomości (działki) lub granic nieruchomości (działek) sąsiednich ${ }^{47}$. Dużo rzadziej spotyka się dystans $8^{48}, 15^{49}$ lub $30 \mathrm{~m}^{50}$. W czterech regulaminach wskazano przy tym, że obligatoryjne odległości mogą być zmniejszone za zgodą właścicieli lub użytkowników nieruchomości ${ }^{51}$. Celem tych wymagań jest zapobieżenie powstawaniu sporów sąsiedzkich. Z tego powodu w orzecznictwie niejednokrotnie

46 Łódź - $\$ 20$ ust. 3 zdanie pierwsze regulaminu, Katowice - $\$ 22$ ust. 3 pkt 2 regulaminu, Rybnik - § 12 pkt 1 lit. b regulaminu.

47 Osiem przypadków wskazanych w regulaminach następujących miast: Warszawa (§ 28 ust. 2 pkt 2), Wrocław (§ 19 ust. 1 pkt 2 - z tym, że jeżeli nieruchomość sąsiednia jest zabudowana budynkiem przeznaczonym na stały pobyt ludzi, obligatoryjna odległość wynosi 30 m), Bydgoszcz ( 13 ust. 8 pkt 2), Białystok ( 21 ust. 3a pkt 2), Opole ( 15 ust. 8 pkt 2), Bielsko-Biała (§ 19 ust. 3), Zielona Góra (§ 53) oraz Legnica (§ 19 ust. 1 pkt 2).

48 Zabrze - $\$ 22$ ust. 1 pkt 3 regulaminu, choć tu zastrzega się dodatkowy warunek, by wylot z ula nie był nakierowany „w stronę najbliższej wobec ula działki sąsiedniej”.

49 Kraków - art. 29 ust. 4 pkt 2 regulaminu oraz Gdynia - $\$ 19$ ust. 3a regulaminu.

50 Torun - $\$ 24$ ust. 7 pkt 2 regulaminu.

51 Zob. regulaminy następujących miast: Warszawa (§ 28 ust. 2 pkt 2$)$, Wrocław (§ 19 ust. 1 pkt 2), Torun (§ 24 ust. 7 pkt 2), Opole (§ 15 ust. 8 pkt 2). 
uznaje się stanowienie takich przepisów za wkroczenie przez radę gminy $\mathrm{w}$ materię prawa sąsied zkiego, regulowaną przepisem art. 144 K.c. ${ }^{52}$ Trzeba jednak zaznaczyć, że przytaczane postanowienia poszczególnych regulaminów nie były kwestionowane przez organy nadzoru, toteż można uznać, że orzecznictwo w tym względzie nie jest jeszcze ustabilizowane i konsekwentne.

W niektórych miastach wymaga się ponadto zachowania większej odległości, o ile nieruchomość sąsiednia zabudowana jest różnego rodzaju budynkami. W Zabrzu odległość ta powinna wynosić co najmniej $20 \mathrm{~m}^{53}$, we Wrocławiu - co do zasady nie mniej niż $30 \mathrm{~m}^{54}$, a w Szczecinie $100 \mathrm{~m}^{55}$. W Legnicy wprowadzono zaś nakaz zachowania odległości $150 \mathrm{~m}$ od „szkół, przychodni, domów opieki i podobnych obiektów użyteczności publicznej" 56 , przy czym nie dotyczy to pasiek do 10 rodzin pszczelich.

O ile idea ustanawiania zwiększonych minimalnych odległości od budynków jest zrozumiała i godna poparcia, o tyle wydaje się, że w niektórych przypadkach może tu dochodzić do konfliktu z art. 144 K.c. Będą to sytuacje, w których minimum to ustanowione jest w odniesieniu do budynków niebędących obiektami użyteczności publicznej. Co do tych ostatnich ograniczenia wydają się jak najbardziej zasadne - chodzi tu o ochronę osób trzecich, niemających prawa do wystąpienia z roszczeniami z tytułu immisji. Specyficzna i trudna do oceny wydaje się zaś sytuacja, gdy mowa jest o budynku mieszkalnym, nieprzeznaczonym do użytku publicznego, lecz obejmującym co najmniej kilka nieruchomości lokalowych. Obszary zabudowane budynkami wielolokalowymi są przecież intensywnie użytkowane również przez osoby, które nie są właścicielami znajdujących się tam nieruchomości lokalowych.

52 Zob. wyrok WSA w Poznaniu z dnia 15 października 2015 r., IV SA/Po 585/15, LEX nr 1933093; rozstrzygnięcie nadzorcze Wojewody Warmińsko-Mazurskiego z dnia 3 stycznia 2013 r., PN.4131.11.13, LEX nr 1276258; wyrok WSA w Gliwicach z dnia 14 sierpnia 2014 r., II SA/G1 482/14, LEX nr 1513325.

$53 \S 22$ ust. 1 pkt 3 regulaminu.

54 § 19 ust. 1 pkt 4 regulaminu, przy czym standardowa odległość od nieruchomości wynosi w tym przypadku $10 \mathrm{~m}$.

$55 \S 12$ pkt 1 regulaminu; zob. także: Lublin - 113 ust. 6 pkt 1 regulaminu oraz Opole $\S 15$ ust. 9 regulaminu.

$56 \S 19$ ust. 1 pkt 3 regulaminu. 
Wątpliwości nie budzą nakazy zachowania odpowiedniej odległości od dróg publicznych. Typową odległością jest $10 \mathrm{~m}^{57}$, ale w Zabrzu jest to $20 \mathrm{~m}^{58}$, zaś w Szczecinie $-30 \mathrm{~m}^{59}$. W regulaminie lubelskim odnajdujemy nakaz, by ule były ustawione w odległości co najmniej $50 \mathrm{~m}$ od dróg szybkiego ruchu ${ }^{60}$. To przepis jawnie nawiązujący do propozycji z KDPP, lecz jednocześnie trudno uznać, by był on - wzorem poprzednich uregulowań - nakierowany na zapewnienie bezpieczeństwa osobom trzecim. Celem jest zabezpieczenie samych pszczół przed potrąceniem, co leży $\mathrm{w}$ interesie gospodarczym pszczelarza, ale jednocześnie może być uznane za instrument humanitarnej ochrony pszczół ${ }^{61}$.

W regulaminach niejednokrotnie wymaga się również odpowiedniego zabezpieczenia terenu posadowienia uli. Najczęściej obowiązek ten wyraża się bardzo ogólnie, wskazując, przykładowo, że chodzi tu o „usytuowanie uli w miejscach uniemożliwiających przypadkowe wejście osób postronnych" ${ }^{2}$. Stosunkowo rzadko wymaga się ogrodzenia nieruchomości ${ }^{63}$. Częstsze jest wymaganie, by ule oddzielone były „stałą przeszkodą (parkan, mur, krzewy) o wysokości co najmniej 3 m, która spowoduje wznoszenie się wylatujących i powracających do ula pszczół nad pobliskim terenem" ${ }^{64}$, co jest kolejnym nakazem wprost zaczerpniętym z KDPP.

W sześciu badanych miastach ustanowiono również nakazy oznakowania terenów utrzymywania pszczół odpowiednimi tabliczkami informacyjnymi ${ }^{65}$.

57 Odległość taką przewidziano w regulaminach następujących miast: Lublin - § 13 ust. 6 pkt 1; Bydgoszcz - $\$ 13$ ust. 8 pkt 2; Opole - $\$ 15$ ust. 8 pkt 2; Legnica - $\$ 19$ ust. 1 pkt 2 .

58 Od „drogi, chodnika, ścieżki lub działki użytkowanych publicznie” - § 22 ust. 1 pkt 3 regulaminu.

$59 \S 10$ ust. 4 regulaminu.

$60 \S 13$ ust. 6 pkt 1 regulaminu.

61 Zob. wyrok SA w Białymstoku z dnia 1 marca 2013 r., I ACa 835/12, LEX nr 1294703.

${ }^{62}$ Warszawa - $\$ 28$ ust. 2 pkt 1 regulaminu; zob. także regulaminy miast: Łódź - $\$ 20$ ust. 3 zdanie pierwsze, Białystok - $\$ 21$ ust. 3 a pkt 1, Katowice $-\S 22$ ust. 3 pkt 2, Legnica $\S 19$ ust. 1 pkt 1 , Torun $-\S 24$ ust. 7 pkt 1 .

${ }^{63}$ Kraków - art. 29 ust. 4 pkt 1 regulaminu oraz Bydgoszcz - $\S 13$ ust. 8 pkt 1 i 2 regulaminu.

64 Kalisz - $§ 28$ regulaminu; zob. również: Opole - $\$ 15$ ust. 9, Kraków - art. 29 ust. 4 pkt 1 i 2 , Szczecin $-\S 10$ ust. 4 oraz Bydgoszcz $-\S 13$ ust. 8 pkt 2.

65 Warszawa $-\S 28$ ust. 2 pkt 1 , Białystok $-\S 21$ ust. 3a pkt 1 , Torun $-\S 24$ ust. 7 pkt 1 , Opole $-\S 15$ ust. 8 pkt 1, Rybnik - §12 ust. 4 pkt 2 oraz Legnica - $\S 19$ ust. 1 pkt 1 . 
Ad 2. Na obszarze miast stosunkowo często ule ustawia się na dachach budynków, w tym również mieszkalnych. Zjawisko to zostało dostrzeżone $\mathrm{w}$ regulaminach ośmiu miast, przy czym w zdecydowanej większości regulacje te ograniczają się do wskazania, by ule były ustawione w odpowiedniej odległości od okien znajdujących się na poziomie i powyżej poziomu posadowienia uli na dachu. Chodzi tu oczywiście o okna w sąsiednich budynkach. W sześciu miastach odległość tę określono na $10 \mathrm{~m}^{66}$, zaś w Gdyni - na $15 \mathrm{~m}^{67}$. Najbardziej rozbudowaną regulację dotyczącą utrzymywania pszczół na dachach zawarto w regulaminie krakowskim $^{68}$. Budynek, na którym mają być postawione ule, nie może być wyższy niż $25 \mathrm{~m}$ - co wydaje się podyktowane naturalnymi potrzebami samych pszczół. Pszczoły muszą mieć zapewniony dostęp do poideł $\mathrm{z}$ wodą, co z jednej strony ma charakter humanitarny, ale może też ograniczyć pszczołom obszar poszukiwań wody. Właściciel pasieki powinien również zawrzeć umowę ubezpieczenia odpowiedzialności cywilnej oraz uzyskać pisemną zgodę właściciela lub zarządcy budynku na prowadzenie pasieki. Co ciekawe, nie ustanowiono jednak obowiązku zachowania odpowiedniej odległości od otworów okiennych - nakazuje się jedynie, by ule znajdowały się co najmniej $5 \mathrm{~m}$ od krawędzi dachu.

W tym miejscu można też wskazać na wyrażone w niektórych regulaminach zakazy utrzymywania pszczół na balkonach budynków wielorodzinnych ${ }^{69}$ oraz $\mathrm{w}$ innych pomieszczeniach nieprzeznaczonych do tego celu, takich jak strychy, piwnice, komórki czy garaże $\mathrm{e}^{70}$.

Ad 3. W ośmiu badanych miastach wprowadzono wymogi co do odmian pszczól, które mogą być utrzymywane na terenach wyłączonych z produkcji rolniczej. Jedynie w Gdyni jest to wymóg, by utrzymywane pszczoły miodne pochodziły z linii dopuszczonych do hodowli na terenie województwa pomorskiego, co prawdopodobnie stanowi nawiązanie do instytucji uchwały sejmiku województwa w sprawie dopuszczenia do

${ }^{66} \mathrm{~W}$ regulaminach miast: Warszawa - $\$ 28$ ust. 2 pkt 3; Wrocław $-\S 19$ ust. 1 pkt 3; Lublin $-\S 13$ ust. 6 pkt 5; Opole $-\S 15$ ust. 8 pkt 3; Legnica $-\S 19$ ust. 1 pkt 4; Torun $-\S 24$ ust. 7 pkt 3 .

$67 \S 19$ ust. 3a regulaminu.

${ }_{68}$ Art. 29 ust. 4 pkt 3 regulaminu.

69 Łódź - $\$ 2$ ust. 3 zdanie drugie regulaminu; Katowice - $\S 22$ ust. 3 pkt 3 regulaminu; Rybnik - §12 pkt 1 lit. c regulaminu.

70 Szczecin $-\S 11$ pkt 2, regulaminu Lublin $-\S 13$ ust. 3 pkt 2 regulaminu; Opole $-\S 15$ ust. 13 pkt 2 regulaminu. 
utrzymywania na terenie województwa jedynie pszczół określonych linii. W tym zakresie przepis regulaminu zdaje się powtarzać regulacje ustawo$\mathrm{we}^{71}$. W pozostałych przypadkach nakazuje się, by utrzymywane pszczoły cechowały się obniżoną agresywnością wobec otoczenia (były łagodne) oraz niską rojliwością ${ }^{72}$.

Ad 4. Określanie maksymalnej liczby utrzymywanych pni pszczelich zdarza się $\mathrm{w}$ regulaminach relatywnie rzadko. W badanej grupie dotyczy to zaledwie czterech regulaminów, a dodatkowo limity były mocno zróżnicowane: od trzech w Olsztynie ${ }^{73}$, przez pięć w Szczecinie $^{74}$ i w Lublinie $^{75}$, do ośmiu w Gdyni ${ }^{76}$. Nie jest do końca jasne, czy ustanowione limity dotyczą maksymalnej liczby pni pszczelich utrzymywanych na tej samej nieruchomości czy też przez tego samego właściciela. W jasny sposób przesądzono o tym tylko w Gdyni, gdzie mówi się o „ilości nie większej niż 8 rojów na posesję"77. Z kolei w Krakowie maksymalną liczbę pni pszczelich ustanowiono jedynie w odniesieniu do utrzymywania tych owadów na dachach budynków - na jedynym dachu może znajdować się do pięciu pni pszczelich, a ich liczba na jeden kilometr kwadratowy miasta nie może przekraczać dwudziestu ${ }^{78}$.

\section{Zakończenie}

Przeniesienie na samorządy terytorialne głównego ciężaru ustanowienia regulacji dla pszczelarstwa miejskiego wydaje się słusznym rozwiązaniem. W tej chwili brak jeszcze uznanych wzorców dla takich przepisów, co jest być może przyczyną tak dużej popularności KDPP jako pewnego szablonu. Systematyczna obserwacja przepisów przyjmowanych

71 Art. 33 ust. 2 ustawy o organizacji hodowli i rozrodzie zwierząt gospodarskich.

${ }^{72}$ Zob. regulaminy miast: Warszawa ( $\$ 28$ ust. 2 pkt 4); Białystok (§ 21 ust. 3a pkt 3); Gdynia (§ 19 ust. 3a); Legnica (§ 19 ust. 1 pkt 5); Rybnik (§ 12 pkt 1 lit. a); Opole (§ 15 ust. 8 pkt 4); Katowice (§ 22 ust. 3 pkt 1); Lublin (§ 13 ust. 7).

$73 \S 16$ regulaminu.

$74 \S 10$ ust. 6 pkt 1 lit. d regulaminu.

$75 \S 13$ ust. 2 pkt 3 lit. c regulaminu.

76 \& 19 ust. 3a regulaminu.

77 § 19 ust. 3a regulaminu.

78 Art. 29 ust. 4 pkt 3 regulaminu. 
w gminach może przyczynić się do stworzenia prawdziwie wzorcowej regulacji zagadnień pszczelarstwa miejskiego. Już teraz można jednak wskazać na praktyki zasługujące na pozytywną bądź negatywną ocenę.

Regulaminy nie mogą pomijać zasadniczej odrębności pszczół od innych zwierząt gospodarskich. Szczególnie zaś trzeba przestrzegać przed ustanowieniem wymagań, których nie da się zachować przy utrzymywaniu pszczół. Nie wydaje się, by pszczoły były w warunkach miejskich gatunkiem bardziej uciążliwym od bydła domowego, tymczasem niektórzy prawodawcy lokalni są bardziej otwarci na obecność w mieście byków i krów niż pszczół. Wydaje się, że takie ograniczenia wynikają wyłącznie z nieuwagi i nieświadomości problemu.

Warto zadbać o określenie minimalnych odległości od dróg i innych obiektów użyteczności publicznej - przede wszystkim dla zapewnienia ich użytkownikom wolności od lęku przed pożądleniem. Zaskakujący jest fakt, że w tak niewielu miastach postanowiono uregulować problematykę sadowienia uli na dachach budynków. W przyszłości należy się przecież spodziewać rosnącego zagęszczenia pni pszczelich właśnie $\mathrm{w}$ tej części przestrzeni miejskiej. Można wyrazić wątpliwość, czy i w tym przypadku nie będziemy mieć do czynienia z wyjściem poza zakres delegacji ustawowej i wkroczeniem w problematykę prawa sąsiedzkiego. W praktyce jednak nie zaobserwowaliśmy, by organy nadzoru i sądy administracyjne wyrażały zastrzeżenia wobec regulacji dotyczących umieszczania uli na dachach budynków.

Stosunkowo mało samorządów zwraca uwagę na konieczność zapobiegania rójkom w terenie miejskim. Jedynie siedem spośród badanych gmin ustanowiło obowiązek wyboru rasy czy linii pszczół cechujących się łagodnością i niską rojliwością. W tym zakresie warto jeszcze przywołać pewną ideę wcielaną już w życie w przywoływanej niejednokrotnie Ljubljanie. W mieście tym działa „zespół szybkiego reagowania”, dostępny pod numerem alarmowym 112, który jest odpowiedzialny za niesienie pomocy między innymi w wypadku, gdy rój ucieknie z pasieki ${ }^{79}$. Wydaje się, że takie rozwiązania można próbować przenieść również do Polski.

W prawodawstwie często traci się z pola widzenia fakt, że pszczoły powinny być chronione ze względu na swoją samoistną wartość. $\mathrm{Na}$

79 Zob. Life is Sweet: On the Hunt with Slovenia's „Rapid Response” Beekeeper Unit [online], https:/ / www.theguardian.com/cities/2018/sep/28/swarm-alert-slovenias-rapid-bee-response-team-in-action [dostęp: 31.08.2019 r.]. 
poparcie i wyróżnienie zasługują takie rozwiązania, jak określenie minimalnej odległości uli od dróg szybkiego ruchu, wskazanie maksymalnej wysokości budynków, na dachach których możliwe jest sadowienie uli, czy narzucenie obowiązku zapewnienia pszczołom stałego dostępu do wody. Warto także zadbać o wdrażanie w miastach rozwiązań zapobiegających przepszczeleniu. Ewentualne niedobory pokarmu mogą bowiem prowadzić do rabunków dokonywanych przez silniejsze rodziny pszczele na słabszych ${ }^{80}$. Prawdopodobnie niewystarczające jest tutaj ograniczenie liczby pni pszczelich na jednej nieruchomości. Ciekawsze jest za to krakowskie rozwiązanie łączące tego rodzaju limit z limitem dwudziestu uli na kilometr kwadratowy.

Nie jest wykluczone, że w przyszłości część lokalnych rozwiązań doczeka się przeniesienia na poziom ustawowy, o ile pomyślnie przejdą one "testy terenowe". Przyczyni się to do ujednolicenia standardów i ich wzmocnienia. Może to dotyczyć przede wszystkim przepisów z pierwiastkiem humanitarnym - chroniących nie tyle ludzi, co same pszczoły. Trudno jednak ocenić, czy pszczoły w Polsce będą kiedyś chronione za pomocą szczególnej ustawy ${ }^{81}$. Szanse na taką ochronę są jednak tym większe, im większa będzie społeczna świadomość specyfiki pszczół oraz ich istotności dla środowiska, a także niebezpiecznej sytuacji, w jakiej obecnie są te owady.

Słowa kluczowe: pszczoły miodne, prawo administracyjne, prawo miejscowe, regulamin utrzymania czystości i porządku w gminie

80 Zob. M. Winiarski, Jak dobrze mieć sąsiada (oby nie za silnego!) [online], Pasieka 2015, nr 4, https://www.pasieka24.pl/index.php/pl-pl/biblioteczka-pszczelarza-z-pasja-ksiazki-pasieki/137-pasieka/pasieka-4-2015/1449-jak-dobrze-miec-sasiada-oby-nie-za-silnego [dostęp: 31.08.2019 r.].

81 Na temat rozwiązań duńskich zob. Z. Witkowski, Ochrona prawna pszczót w Polsce [online], serwis internetowy: Pasieka24, https://pasieka24.pl/index.php/pl-pl/biblioteczka-pszczelarza-z-pasja-ksiazki-pasieki/168-ochrona-prawna-pszczol/1840-rozdzial-vii [dostęp: 20.08.2019 r.]. 


\section{Bibliografia}

\section{Źródła}

\section{Akty prawne}

Ustawa z dnia 23 kwietnia 1964 r. - Kodeks cywilny, tekst jednolity: Dz. U. z 2019 r. poz. 1145 z późn. zm.

Ustawa z dnia 20 maja 1971 r. - Kodeks wykroczeń, tekst jednolity: Dz. U. z 2019 r. poz. 821 z późn. zm.

Ustawa z dnia 3 lutego 1995 r. o ochronie gruntów rolnych i leśnych, tekst jednolity: Dz. U. z 2017 r. poz. 1161.

Ustawa z dnia 13 września 1996 r. o utrzymaniu czystości i porządku w gminach, tekst jednolity: Dz. U. z 2019 r. poz. 2010 z późn. zm.

Ustawa z dnia 29 czerwca 2007 r. o organizacji hodowli i rozrodzie zwierząt gospodarskich, tekst jednolity: Dz. U. z 2017 r. poz. 2132.

Uchwała Nr VI/95/15 Rady Miasta Gdańska z dnia 26 lutego 2015 r. w sprawie Regulaminu utrzymania czystości i porządku na terenie miasta Gdańska, tekst jednolity: Dz. Urz. Woj. Pomorskiego z 2018 r. poz. 3863 z późn. zm.

Załącznik do uchwały Nr 72.IX.2015 Rady Miasta Częstochowy z dnia 19 marca 2015 r. w sprawie regulaminu utrzymania czystości i porządku na terenie miasta Częstochowy, Dz. Urz. Woj. Śląskiego z 2015 r. poz. 1734 z późn. zm.

Uchwała Nr VI/99/2015 Rady Miasta Kielce z dnia 19 marca 2015 r. w sprawie regulaminu utrzymania czystości i porządku na terenie Miasta Kielce, Dz. Urz. Woj. Świętokrzyskiego z 2015 r. poz. 1045 z późn. zm.

Uchwała Nr VI/81/15 Rady Miasta Szczecin z dnia 24 marca 2015 r. w sprawie wprowadzenia Regulaminu utrzymania czystości i porządku na terenie Gminy Miasto Szczecin, Dz. Urz. Woj. Zachodniopomorskiego z 2015 r. poz. 1543 z późn. zm.

Uchwała Nr XI/140/15 Rady Miasta Bydgoszczy z dnia 29 kwietnia 2015 r. w sprawie uchwalenia regulaminu utrzymania czystości i porządku na terenie Miasta Bydgoszczy, Dz. Urz. Woj. Kujawsko-Pomorskiego z 2015 r. poz. 1625 z późn. zm.

Załącznik do uchwały Nr VII/78/2015 Rady Miejskiej w Elblągu z dnia 28 maja 2015 r. w sprawie Regulaminu utrzymania czystości i porządku na terenie Gminy Miasto Elbląg, Dz. Urz. Woj. Warmińsko-Mazurskiego z 2017 r. poz. 3652.

Załącznik do uchwały Nr VIII/171/2015 Rady Miejskiej w Dąbrowie Górniczej z dnia 24 czerwca 2015 r. w sprawie ustalenia szczegółowych zasad utrzymania czystości i porządku na terenie gminy Dąbrowa Górnicza, Dz. Urz. Woj. Śląskiego z 2015 r. poz. 3507 z późn. zm. 
Uchwała Nr X/182/15 Rady Miasta Gdyni z dnia 24 czerwca 2015 r. w sprawie regulaminu utrzymania czystości i porządku na terenie miasta Gdyni, Dz. Urz. Woj. Pomorskiego z 2015 r. poz. 2242 z późn. zm.

Załącznik do uchwały Nr XIV/199/15 Rady Miasta Białystok z dnia 23 listopada 2015 r. w sprawie Regulaminu utrzymania czystości i porządku na terenie Gminy Białystok, tekst jednolity: Dz. Urz. Woj. Podlaskiego z 2018 r. poz. 4003. Załącznik do uchwały Nr XV/201/2015 Rady Miejskiej Wałbrzycha z dnia 26 listopada 2015 r. w sprawie Regulaminu utrzymania czystości i porządku na terenie gminy Wałbrzych, Dz. Urz. Woj. Dolnośląskiego z 2015 r. poz. 5452 z późn. zm.

Uchwała Nr XVIII/319/16 Rady Miasta Tychy z dnia 28 stycznia 2016 r. w sprawie Regulaminu utrzymania czystości i porządku na terenie miasta Tychy, Dz. Urz. Woj. Śląskiego z 2016 r. poz. 867 z późn. zm.

Załącznik do uchwały Nr XIII/323/2016 Rady Miasta Gliwice z dnia 4 lutego 2016 r. w sprawie regulaminu utrzymania czystości i porządku na terenie miasta Gliwice, Dz. Urz. Woj. Śląskiego z 2016 r. poz. 1056.

Załącznik do uchwały Nr XXIV/247/16 Rady Miasta Zabrze z dnia 18 kwietnia 2016 r. w sprawie regulaminu utrzymania czystości i porządku na terenie gminy Zabrze, Dz. Urz. Woj. Śląskiego z 2016 r. poz. 2385.

Uchwała 300/16 Rady Miasta Torunia z dnia 12 maja 2016 r. w sprawie regulaminu utrzymania czystości i porządku na terenie Gminy Miasta Toruń, Dz. Urz. Woj. Kujawsko-Pomorskiego z 2016 r. poz. 1765 z późn. zm.

Załącznik do uchwały Nr 485/XVIII/2016 Rady Miasta Lublin z dnia 19 maja 2016 r. w sprawie Regulaminu utrzymania czystości i porządku na terenie miasta Lublin, tekst jednolity: Dz. Urz. Woj. Lubelskiego z 2018 r. poz. 1017.

Uchwała Nr XXVIII/567/16 Rady Miejskiej Wrocławia z dnia 7 lipca 2016 r. w sprawie regulaminu utrzymania czystości i porządku na terenie Wrocławia, tekst jednolity: Dz. Urz. Woj. Dolnośląskiego z 2019 r. poz. 4609.

Załącznik do uchwały Nr 352/2016 Rady Miejskiej w Radomiu z dnia 29 sierpnia 2016 r. w sprawie Regulaminu utrzymania czystości i porządku na terenie Gminy Miasta Radomia, Dz. Urz. Woj. Mazowieckiego z 2016 r. poz. 7846.

Uchwała Nr XXXI/571/16 Rady Miasta Opola z dnia 29 września 2016 r. w sprawie regulaminu utrzymania czystości i porządku na terenie Miasta Opola, Dz. Urz. Woj. Opolskiego z 2016 r. poz. 2082 z późn. zm.

Uchwała Nr XIX/226/2016 Rady Gminy Tarnów z dnia 29 września 2016 r. w sprawie: uchwalenia Regulaminu utrzymania czystości i porządku na terenie Gminy Tarnów, Dz. Urz. Woj. Małopolskiego z 2016 r. poz. 5712.

Uchwała Nr XLII.505.2016 Rady Miasta Zielona Góra z dnia 20 grudnia 2016 r. w sprawie regulaminu utrzymania czystości i porządku na terenie Miasta Zielona Góra, Dz. Urz. Woj. Lubuskiego z 2016 r. poz. 2763. 
Uchwała Nr 521/XXX/2017 Rady Miasta Płocka z dnia 28 marca 2017 r. w sprawie przyjęcia Regulaminu utrzymania czystości i porządku na terenie miasta Płocka, Dz. Urz. Woj. Mazowieckiego z 2017 r. poz. 4099.

Załącznik do uchwały Nr XXXI/578/2017 Rady Miejskiej w Bielsku-Białej z dnia 20 czerwca 2017 r. w sprawie Regulaminu utrzymania czystości i porządku na terenie miasta Bielska-Białej, Dz. Urz. Woj. Śląskiego z 2017 r. poz. 3857.

Uchwała Nr XXXII/461/2017 Rady Miejskiej w Koszalinie z dnia 22 czerwca 2017 r. w sprawie uchwalenia regulaminu utrzymania czystości i porządku na terenie Miasta Koszalina, Dz. Urz. Woj. Zachodniopomorskiego z 2017 r. poz. 3243.

Załącznik do uchwały Nr XXXVII/ 641/17 Rady Miasta Olsztyna z dnia 28 czerwca 2017 r. w sprawie przyjęcia Regulaminu utrzymania czystości i porządku na terenie Gminy Olsztyn, Dz. Urz. Woj. Warmińsko-Mazurskiego z 2017 r. poz. 3234 z późn. zm.

Załącznik do uchwały Nr LI/637/17 Rady Miejskiej w Bytomiu z dnia 5 września 2017 r. w sprawie regulaminu utrzymania czystości i porządku na terenie miasta Bytomia, Dz. Urz. Woj. Śląskiego z 2017 r. poz. 4993.

Uchwała Nr XLVII/871/17 Rady Miasta Katowice z dnia 21 września 2017 r. w sprawie Regulaminu utrzymania czystości i porządku na terenie Miasta Katowice, Dz. Urz. Woj. Śląskiego z 2017 r. poz. 5173.

Uchwała Nr XLI/750/17 Rady Miasta Chorzów z dnia 28 września 2017 r. w sprawie Regulaminu utrzymania czystości i porządku na terenie Miasta Chorzów, Dz. Urz. Woj. Śląskiego z 2017 r. poz. 5320 z późn. zm.

Załącznik do uchwały Nr LVI/1025/VII/2017 Rady Miasta Poznania z dnia 7 listopada 2017 r. w sprawie przyjęcia Regulaminu utrzymania czystości i porządku na terenie miasta Poznania, Dz. Urz. Woj. Wielkopolskiego z 2017 r. poz. 7458 z późn. zm.

Załącznik do uchwały Nr XXIX/219/17 Rady Gminy Włocławek z dnia 23 listopada 2017 r. w sprawie uchwalenia Regulaminu utrzymania czystości i porządku na terenie Gminy Włocławek, Dz. Urz. Woj. Kujawsko-Pomorskiego z 2017 r. poz. 4876.

Uchwała Nr 800/LVIII/2018 Rady Miejskiej w Sosnowcu z dnia 30 stycznia 2018 r. w sprawie regulaminu utrzymania czystości i porządku na terenie miasta Sosnowca, Dz. Urz. Woj. Śląskiego z 2018 r. poz. 823 z późn. zm.

Uchwała Nr LVIII/728/2018 Rady Miasta Gorzowa Wielkopolskiego z dnia 31 stycznia 2018 r. w sprawie regulaminu utrzymania czystości i porządku na terenie Miasta Gorzowa Wlkp., Dz. Urz. Woj. Lubuskiego z 2018 r. poz. 354.

Załącznik do uchwały Nr LXI/1631/2018 Rady Miasta Stołecznego Warszawy z dnia 8 lutego 2018 r. w sprawie Regulaminu utrzymania czystości i porządku na terenie m.st. Warszawy, Dz. Urz. Woj. Mazowieckiego z 2018 r. poz. 1968. 
Uchwała Nr XLIII/462/18 Rady Miejskiej Legnicy z dnia 26 lutego 2018 r. w sprawie ustalenia Regulaminu utrzymania czystości i porządku na terenie Gminy Legnica, Dz. Urz. Woj. Dolnośląskiego z 2018 r. poz. 1149.

Załącznik do uchwały Nr LXIX/1770/18 Rady Miejskiej w Łodzi z dnia 29 marca 2018 r. w sprawie wprowadzenia Regulaminu utrzymania czystości i porządku na terenie Miasta Łodzi, Dz. Urz. Woj. Łódzkiego z 2018 r. poz. 2308.

Uchwała Nr LIX/1380/2018 Rady Miasta Rzeszowa z dnia 22 maja 2018 r. w sprawie uchwalenia Regulaminu utrzymania czystości i porządku na terenie Gminy Miasto Rzeszów, Dz. Urz. Woj. Podkarpackiego z 2018 r. poz. 2776 z późn. $\mathrm{zm}$.

Załącznik do uchwały Nr PR.0007.92.2018 Rady Miasta Ruda Śląska z dnia 24 maja 2018 r. w sprawie Regulaminu utrzymania czystości i porządku na terenie Miasta Ruda Śląska, Dz. Urz. Woj. Śląskiego z 2018 r. poz. 3680.

Załącznik do uchwały Nr III/35/18 Rady Miasta Krakowa z dnia 19 grudnia 2018 r. w sprawie Regulaminu utrzymania czystości i porządku na terenie Gminy Miejskiej Kraków, Dz. Urz. Woj. Małopolskiego z 2018 r. poz. 8964.

Załącznik do uchwały Nr IX/123/2019 Rady Miasta Kalisza z dnia 14 maja 2019 r. w sprawie uchwalenia Regulaminu utrzymania czystości i porządku na terenie miasta Kalisza, Dz. Urz. Woj. Wielkopolskiego z 2019 r. poz. 5140.

Załącznik do uchwały Nr 136/XI/2019 Rady Miasta Rybnika z dnia 24 maja 2019 r. w sprawie Regulaminu utrzymania czystości i porządku na terenie Miasta Rybnika, Dz. Urz. Woj. Śląskiego z 2019 r. poz. 4106.

\section{Orzecznictwo}

Wyrok SN z dnia 28 grudnia 1979 r., III CRN 249/79, OSNC 1980/7-8/144.

Wyrok NSA z dnia 29 kwietnia 2009 r., II OSK 1953/08, LEX nr 597454.

Wyrok WSA w Gliwicach z dnia 14 sierpnia 2014 r., II SA/Gl 482/14, LEX nr 1513325.

Wyrok WSA w Warszawie z dnia 11 września 2015 r., IV SA/Wa 1435/15, LEX nr 2327557.

Wyrok WSA w Poznaniu z dnia 15 października 2015 r., IV SA/Po 585/15, LEX nr 1933093.

Wyrok WSA w Warszawie z dnia 10 lutego 2017 r., IV SA/Wa 2661/16, LEX nr 2396075.

Wyrok SA w Białymstoku z dnia 1 marca 2013 r., I ACa 835/12, LEX nr 1294703. Wyrok SA w Łodzi z 8 kwietnia 2015 r., I ACa 1472/14, LEX nr 1680038.

Wyrok SR w Suchej Beskidzkiej z dnia 20 lipca 2016 r., I C 19/15, http:/ / orzeczenia.ms.gov.pl/details/\$N/152010550000503_I_C_000019_2015_Uz_2016-0720_001 [dostęp: 20.08.2019 r.]. 
Wyrok SR w Gorlicach z dnia 7 grudnia 2016 r., I C 255/16, http:/ / orzeczenia. ms.gov.pl/details/\$N/152015050000503_I_C_000255_2016_Uz_2016-1207_001 [dostęp: 20.08.2019 r.].

Wyrok SR w Świdnicy z dnia 25 stycznia 2017 r., I C 1522/16, http:/ / orzeczenia.ms.gov.pl/details/\$N/155020150000503_I_C_001522_2016_Uz_2017-0206_001 [dostęp: 20.08.2019 r.].

Decyzja SKO w Katowicach z dnia 7 stycznia 2014 r., SKO-OG/43/75/13875/13, LEX nr 1427612.

Rozstrzygnięcie nadzorcze Wojewody Warmińsko-Mazurskiego z dnia 3 stycznia 2013 r., PN.4131.11.13, LEX nr 1276258.

\section{Literatura}

Banaszak-Cibicka W. i in., City Parks vs. Natural Areas - Is It Possible to Preserve a Natural Level of Bee Richness and Abundance in a City Park?, Urban Ecosystem 2018, t. 21.

Buczek J., Cywilnoprawna problematyka hodowli pszczót, Przegląd Sądowy 2003, nr 2. Burr A. i in., Wild Bees in the City: Reimagining Urban Spaces for Native Bee Health, Consilience: The Journal of Sustainable Development 2016, t. 16.

Goettel M., Sytuacja zwierzeccia w prawie cywilnym, Warszawa 2013.

Hagler J.R. i in., Foraging Range of Honey Bees, ,'Apis mellifera", in Alfalfa Seed Production Fields, Journal of Insect Science 2011, t. 11.

Haładyj A., J. Trzewik, Lokalizacja pni pszczelich na tle regulacji prawa administracyjnego i prawa cywilnego, Studia Prawnoustrojowe 2017, nr 37.

Helping Honey Bees and other London Pollinators [online], http://www.lbka.org.uk/ downloads/LBKA_helping_honey_bees_A4_digital_v3.pdf [dostęp: 20.09.2019r.].

Ilič N., BeePathNet Boot Camp [online], https:/ / zavodeneja.wixsite.com/api-programi/single-post/2019/04/15/BeePathNet oraz https://urbact.eu/bee-path [dostęp: 20.08.2019 r.].

Langellotto G.A. i in., Garden Pollinators and the Potential for Ecosystem Service Flow to Urban and Peri-Urban Agriculture, Sustainability 2018, t. 10.

Life is Sweet: On the Hunt with Slovenia's "Rapid Response" Beekeeper Unit [online], https:/ / www.theguardian.com/cities/2018/sep/28/swarm-alert-slovenias-rapid-bee-response-team-in-action [dostęp: 31.08.2019 r.].

Marinelli J., Urban Refuge: How Cities Can Help Rebuild Declining Bee Populations [online], https://e360.yale.edu/features/urban-refuge-how-cities-can-help-rebuild-declining-bee-populations [dostęp: 20.08.2019 r.].

Matteson K.C., J.S. Ascher, G.A. Langellotto, Bee Richness and Abundance in New York City Urban Gardens, Annals of the Entomological Society of America 2008, t. 101. 
Michołap P., A. Sikora, Dzikie pszczoły w mieście i możliwości ich protekcji, w: Ochrona pszczót i pszczelarstwo w badaniach młodych naukowców, red. E.M. Szymański, D. Dyrda, Zgorzelec 2016.

Ljubljana Most Bee-Friendly Municipality 2017 [online], https:/ / www.ljubljana.si/ en/about-ljubljana/award-winning-ljubljana/ljubljana-most-bee-friendly-municipality-2/ [dostęp: 20.08.2019 r.].

Oslo Creates World's First 'Highway' to Protect Endangered Bees [online], The Guardian, https://www.theguardian.com/environment/2015/jun/25/oslo-creates-worlds-first-highway-to-protect-endangered-bees [dostęp: 20.08 .2019 r.].

Radecki W., Komentarz do art. 4 ustawy o utrzymaniu czystości i porządku w gminach, LEX 2016.

Samuelson A.E. i in., City Bees out Breed their Country Cousins [online], https:// www.royalholloway.ac.uk/about-us/news/city-bees-out-breed-their-country-cousins/ [dostęp: 20.08.2019 r.].

The Bee Path [online], https://www.ljubljana.si/en/ljubljana-for-you/environmental-protection/the-bee-path/ [dostęp: 20.08.2019 r.].

Winiarski M., Jak dobrze mieć sąsiada (oby nie za silnego!) [online], Pasieka 2015, nr 4, https://www.pasieka24.pl/index.php/pl-pl/biblioteczka-pszczelarza-z-pasja-ksiazki-pasieki/137-pasieka/pasieka-4-2015/1449-jak-dobrze-miec-sasiada-oby-nie-za-silnego [dostęp: 31.08.2019 r.].

Witkowski Z., Ochrona prawna pszczół w Polsce [online], serwis internetowy: Pasieka24, https://pasieka24.pl/index.php/pl-pl/biblioteczka-pszczelarza-z-pasja-ksiazki-pasieki/168-ochrona-prawna-pszczol/1840-rozdzial-vii [dostęp: 20.08.2019 r.].

Valentin L., Challenges and Opportunities in Swedish Apiculture [online], https:/ / stud.epsilon.slu.se/6181/8/valentin_1_131015.pdf [dostęp: 20.08.2019 r.].

\section{HONEY BEES IN LOCAL LAW}

\section{Summary}

Threats to which honey bees are exposed to, especially the phenomenon of their mass disappearance, lead to the search for new living areas for those insects. Such areas may be cities, which in some respects constitute an appropriate habitat for bees. Urban beekeeping raises some legal challenges, primarily related to the need to protect bees on the one hand, and on the other to ensure people's freedom from fear of stings. Traditional instruments of civil and criminal law do not apply to the new situation; so administrative law must play a leading role in this regard. Many Polish cities are already trying to govern the requirements for keeping bees in cities. The main purpose of this article is to review and evaluate 
local regulations, and then to identify good and bad practices in the field of legal regulations of urban beekeeping.

Key words: honey bee, administrative law, local law, law of maintaining cleanliness and order in the municipality

\section{МЕДОНОСНЫЕ ПЧЕЛЫ В МЕСТНОМ ПРАВЕ}

\section{Резюме}

Опасности, подстерегающие медоносных пчел, проявляющиеся, в особенности, в явлении их массового исчезновения, склоняют к поиску новых районов обитания для этих насекомых.

Такими районами могут быть города, которые во многих отношениях оказываются очень хорошим местом для жизни пчел. Городское пчеловодство порождает некоторые правовые проблемы, в первую очередь связанные с необходимостью защищать, с одной стороны, самих пчел, а с другой - обеспечить свободу людей от страха быть ужаленными. Традиционные инструменты гражданского и уголовного права не соответствуют новой ситуации; ведущую роль в этом отношении должно играть административное право. Многие польские города уже пытаются регулировать требования по содержанию пчел в городах. Основной целью данной статьи является обзор и оценка местных законов, а затем представление положительных и отрицательных практик в области правового регулирования городского пчеловодства.

Ключевые слова: медоносные пчелы, административное право, местное право, правила поддержания чистоты и порядка в гмине 
